\title{
Development of an evidence-based model of rapid testing, counseling and referral patients with HIV, HVC and other STDs in Mexican addiction treatment centers
}

\author{
Rodrigo Marín-Navarrete, ${ }^{1}$ Carlos Magis-Rodríguez, ${ }^{2}$ Luis Villalobos-Gallegos ${ }^{3}$ Adriana Villafuerte-García, ${ }^{2}$ \\ Alejandro Pérez-López, ${ }^{1}$ Karen Ruiz-Herrera, ${ }^{2}$ Ricardo Sánchez-Domínguez, ${ }^{1}$ Marisol Ponce-Ramos, ${ }^{2}$ \\ Anette Morales-Carcaño, ${ }^{2}$ Enrique Bravo-García ${ }^{2}$ Patricia Uribe Zúñiga ${ }^{2}$ María Elena Medina-Mora
}

Unidad de Ensayos Clínicos en Adicciones y Salud Mental, Instituto Nacional de Psiquiatría Ramón de la Fuente Muñiz. Ciudad de México, México.

2 Centro Nacional para la Prevención y el Control del VIH y el Sida. Ciudad de México, México.

3 Facultad de Medicina y Psicología, Universidad Autónoma de Baja California-Campus Tijuana, México.

\section{Correspondence:}

Rodrigo Marín-Navarrete

Instituto Nacional de Psiquiatría Ramón de la Fuente Muñiz, Unidad de Ensayos Clínicos en Adicciones y Salud Mental.

Calz. México-Xochimilco 101

San Lorenzo Huipulco, Tlalpan,

14370, Ciudad de México, México.

Phone: +52 554160 - 5480

Email: rmarin@imp.edu.mx

Received: 23 July 2019

Accepted: 20 August 2019

Citation:

Marín-Navarrete, R., Magis-Rodríguez, C., Villalobos-Gallegos, L., Villafuerte-García, A., Pérez-López, A., Ruiz-Herrera, K., ... Medina-Mora, M. E. (2019). Development of an evidence-based model of rapid testing, counseling and referral patients with HIV, HVC and other STDs in Mexican addiction treatment centers. Salud Mental, 42(4), 191-201.

DOI: $10.17711 /$ SM.0185-3325.2019.025

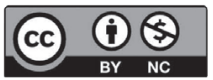

\begin{abstract}
Introduction. Efforts to identify new cases of HIV, HVC and other STIs, through the application of quick tests, focus on people who inject drugs, without taking into account the fact that the use of alcohol and other drugs of abuse inhibits decision making, increasing the transmission of STIs through risky sexual practices. Accordingly, it is necessary to have detection algorithms that consider people who use multiple drugs to improve the identification of new cases and their subsequent linkage with health services. Objective. This paper describes the development process of the OPB-APR model for the detection, counseling and referral of people with HIV and other STIs at addiction treatment centers. Method. The procedure is divided into three phases: 1. A literature review to identify the basic concepts of HIV and other STIs, substance use, risky sexual behaviors, quick tests, and specialized psychological counseling; 2. A feasibility study in which a health professional is trained to implement the OPB-APR model; 3. Drafting of the final version. Results. The final version of the OPB-APR model was obtained, which describes standardized procedures for detection, counseling and referral to health services. Discussion and conclusions. The OPB-APR model aims to strengthen the public health system by increasing the coverage of services for the detection of HIV, HCV and other STIs. The above through the implementation of standardized procedures among specialized and non-specialized health professionals of addiction care centers.
\end{abstract}

Keywords: HIV, HCV, STIs, addictions, rapid tests, psychological counseling.

\section{RESUMEN}

Introducción. Los esfuerzos para la identificación de nuevos casos de VIH, VHC y otras ITS, mediante la aplicación de pruebas rápidas, se centra en personas que se inyectan drogas, sin considerar que el consumo de alcohol y otras drogas de abuso inhiben la toma de decisiones incrementando el riesgo de contagio de ITS durante prácticas sexuales de riesgo. Por este motivo, es necesario contar con algoritmos de detección que consideren a personas con múltiples consumos para incrementar la identificación de nuevos casos y su posterior vinculación a servicios de salud. Objetivo. Describir el proceso de desarrollo del modelo OPB-APR para la detección, orientación y referencia de personas con VIH y otras ITS en centros de tratamiento de adicciones. Método. El procedimiento se dividió en tres fases: 1. Revisión de literatura para identificar conceptos básicos sobre el VIH y otras ITS, consumo de sustancias, conductas sexuales de riesgo, pruebas rápidas, y orientación psicológica especializada; 2 . Estudio de factibilidad en el que se entrenó a profesionales de la saludpara implementar el modelo OPB-APR; 3 . Integración de la versión final. Resultados. Se obtuvo la versión final del modelo $O P B-A P R$ el cual describe procedimientos estandarizados para la detección, orientación y referencia a servicios de salud. Discusión y conclusión. El modelo OPB-APR pretende fortalecer al sistema público de salud al incrementar la cobertura de servicios para la detección del VIH, VHC y otras ITS. Lo anterior mediante la implementación de procedimientos estandarizados entre los profesionales de la salud especializados y no especializados de centros para la atención de adicciones.

Palabras clave: VIH, VHC, ITS, adicciones, pruebas rápidas, orientación psicológica. 


\section{INTRODUCTION}

In Mexico, epidemiological monitoring systems estimate that there are approximately 200,000 people living with HIV/AIDS (PLHIV), equivalent to $.24 \%$ of the general population. Estimated prevalence of the Hepatitis $\mathrm{C}$ virus (HCV) is $1.4 \%$ with an annual incidence of approximately 19,300 cases; whereas for the hepatitis B virus (HBV) it has been estimated at between $.16 \%$ and $.33 \%$; while a prevalence of $1.53 \%$ has been found for syphilis (Nattional Center for the Prevention and Control of HIV and AIDS [CENSIDA, by its acronym in Spanish], 2019; Fundación Mexicana para la Salud Hepática, 2011).

It is also known that in Mexico, as in many parts of the world, the HIV epidemic focuses on key populations (CENSIDA, 2019): men who have sex with other men (MSM), persons deprived of their liberty (PDL) or incarcerated, sex workers (SW), transgender people (TP), and people who use drugs of abuse (particularly people who inject drugs [PWIDs]), the latter being one of the major public health concerns, since it is associated with clinical and psychosocial complications that hamper the detection, diagnosis and treatment of any STI or blood-borne viruses (BBV) (Marín-Navarrete, Magis-Rodríguez, \& Strathdee, 2017).

\section{SUDs and their relationship with HIV and other STIs}

International reports estimate that over $50 \%$ of PLHIV have had a substance use disorder (SUD) (Rabkin, McElhiney, \& Ferrando, 2004).

Although it is true that it is necessary to differentiate between a SUD and non-problematic use of alcohol, tobacco and/or other substances of abuse, it has been found that substance use in PLHIV is generally associated with health risk behaviors, immunosuppression, poor adherence to antiretroviral treatment, an increase in the disease burden, greater morbidity and mortality and higher medical care costs (Chander, Himelhoch, \& Moore, 2006). It should also be borne in mind that the use of substances of abuse constitutes an indirect and direct transmission vector. The former is characterized by increasing the likelihood of participating in risky sexual behaviors (unprotected sex, multiple sexual partners, group sex, among others) since it inhibits judgment, heightens sexual arousal and increases impulsivity. The latter is associated with the use of injectable drugs, since PWIDs frequently exchange syringes and other drug paraphernalia, thereby significantly increasing the risk of transmission (Klinkenberg \& Sacks, 2004; Strathdee et al., 2008).

In addition to HIV, the most prevalent BBV in people with SUD is $\mathrm{HCV}$, since a prevalence of over $90 \%$ has been estimated in PWIDs, in addition to the fact that it is associated with a higher risk of co-infection. In this regard, there is evidence that $\mathrm{HCV} / \mathrm{HIV}$ coinfection accelerates the course of HCV infection with fatal outcomes of terminal liver disease (Altice, Kamarulzaman, Soriano, Schechter, \& Friedland, 2010).

Studies have reported that the prevalence of co-infection between HIV and HBV in the general population ranges from 5\% to 20\%, but that in PWIDs it is just under 30\% (Singh et al., 2017; Thio et al., 2002). As with other diseases, HBV/HIV coinfection is common, causing a greater risk of developing liver cirrhosis and hepatocellular carcinoma, with up to sixfold progressions of liver disease (Sulkowski, Thomas, Chaisson, \& Moore, 2000). HIV infection affects the immune system in many ways, which directly or increase: a) HBV liver fibrosis, (depleting CD4 cells, which in turn cause liver damage), b) hepatotoxicity caused by medication, and c) the presence of opportunistic infections (Benhamou et al., 1999; Sulkowski et al., 2000).

Another important STI in drug users is syphilis, for which a prevalence of 3\% is estimated, rising to between $8 \%$ and $20 \%$ for PWIDs (Rhodes et al., 2006; Centers for Disease Control and Prevention, 2019). Since primary syphilis acts as a facilitator of both HIV transmission and acquisition, it is a matter of concern in the expansion of the HIV epidemic in key populations. It has therefore been hypothesized that the increase in the syphilis rate is associated with the increase in recreational use of psychostimulant drugs (such as cocaine, amphetamines, methamphetamines and synthetic cathinones) and alcohol, which can be mitigated by safe sex practices (condom use), whether oral, anal and/or vaginal (Wong, Chaw, Kent, \& Klausner, 2005; Marcus et al., 2006).

Like other infectious conditions, syphilis shows transient increases in viral load and reduces the CD4 cell count. These increases contribute to the risk of HIV transmission, facilitating concordance between the two viruses. (Quinn et al., 2000).

From this perspective, the use of alcohol and other drugs is a transversal axis of utmost importance since virtually all groups in a situation of vulnerability (adolescents, orphans, children in street situations, people with disabilities, migrants, women and indigenous people) and key populations (MSM, PDL, SW, TP and PWIDs) are susceptible to use substances and develop SUDs (Scheinmann et al., 2007).

\section{Barriers to access to STIs treatment services in substance users}

Among substance users, there are barriers that limit help seeking, which impacts detection, diagnosis and treatment. In this regard, the specialized literature identifies the following as barriers: a) lack of knowledge of medical comorbidities and their impact on health, b) misperceptions about STIs and their treatment, c) lack of symptoms, d) employment status (self-employment/unemployment), 
e) unstable housing (people in street situations, etc.), f) social stigma and g) difficulties accessing specialized health services (Grebely \& Tyndall, 2011; Treloar, Newland, Rance, \& Hopwood, 2010). In relation to access, HIV is known to disproportionately affect people with limited economic resources, who generally lack social security or insurance policies for medical expenses.

Fortunately, in Mexico, HIV treatment is free, which is not the case for other viruses such as $\mathrm{HCV}$, since access to public services for detection, diagnosis and treatment is limited, a situation associated with the increase in morbimortality due to HCV (Centro de Investigación en Enfermedades Infecciosas [CIENI], 2011).

Another common structural barrier in health systems is the disconnection between programs for the care of SUDs and other mental disorders in programs for the care of HIV/ AIDS and other STIs. The absence of effective reference and counter-reference algorithms makes it difficult and complex for patients to navigate health services (Szerman et al., 2017).

As in other countries, the ability of the Mexican state to respond to major public health problems is limited (Marín-Navarrete, Medina-Mora, Pérez-López, \& Horigian, 2018), as is the case with chronic-degenerative and infecto-contagious diseases, and mental and addictive disorders.

However, Mexico has a growing health system for the care of SUDs, HIV and other STIs. For SUDs, the supply of treatment consists of private care (very expensive for most of the people affected), public care (more than 400 outpatient centers and just under 30 residential units) and mutual assistance (over 20,000 groups based on the 12 AA steps and approximately 2,000 residential community care and peer assistance centers) (Marín-Navarrete, Medina-Mora, \& Tena-Suck, 2014). For HIV/AIDS and other STIs, the supply of public treatment comprises 78 outpatient units (CAPASIT by its acronym in Spanish) and 63 hospital units (SAIH by its acronym in Spanish), which currently lack easily accessible programs for the treatment of HCV (CENSIDA, 2019).

Despite the progress achieved to date, there is a marked gap between both public care systems, due to the absence of reference and counter-reference algorithms to facilitate patients' navigation. This situation highlights the need for inter-institutional models and programs based on scientific evidence that will contribute to the integration of public health systems and facilitate interaction between centers for the treatment of SUDs and centers for the care of HIV and other STIs, with the goal of strengthening the care cascade.

The purpose of this article is to present the narrative of the process for the development of a standardized model based on scientific evidence for the detection, orientation and reference of people with HIV, HBV, HCV and syphilis at addiction treatment centers in the public health system in Mexico.

\section{METHOD}

\section{Study design and sites}

As part of a strategic plan for the development of the model, two collaborative work teams were formed, one consisting of medical science researchers at the Clinical Trials Unit on Addictions and Mental Health of the Ramón de la Fuente Muñiz National Institute of Psychiatry (UEC-INPRFM by its acronym in Spanish), which served as the leading team for the implementation of the study and a team of experts on HIV and other STIs from the National Center for the Prevention and Control of HIV/AIDS (CENSIDA by its acronym in Spanish), who served as specialized advisors. Under a collaborative work scheme, a development methodology of the model was established: a) review of the scientific literature, b) feasibility study, c) integration of the final version of the model.

\section{Procedure}

\section{Section 1: Review of the scientific literature}

A systematic review of the scientific literature was undertaken to identify: a) basic concepts of HIV and other STIs, b) their relationship with the use of alcohol and other drugs of abuse, c) evaluation of risky sexual behaviors, d) application of rapid testing to detect HIV, HCV and other STIs, and e) specialized psychological counseling. The review of the scientific literature was conducted through a systematized search of information from the past five years, using the PubMed, Scielo, and Google Scholar search engines. To this end, a search algorithm was generated that included keywords on the study topics. Articles, guides and scientific manuals were selected through a process of consensus between members of both collaborative work teams, on the basis of their quality and scientific relevance, to ensure that the guides and manuals were written using scientific methods and bases, in addition to being products agreed on by experts and endorsed by prestigious scientific organizations in this field of health knowledge. Following the selection and review of the literature, a group of key recommendations for the development of the model was drawn up: a) general principles of psychological counseling and the application of rapid testing (Table 1), b) considerations for the psychological counseling process and the application of rapid testing (Table 2), c) considerations regarding users of substances of abuse (Table 3), and d) considerations for giving back results and referral to health services (Table 4).

Lastly, the systematic review of the scientific literature made it possible to use scientific evidence to construct a model of Brief psychological counseling for the application of rapid testing ( $O P B-A P R$ by its acronym in Spanish) comprising three key components: a) brief psychological counseling, b) application of rapid testing for the detection 
Table 1

General principles of psychological counseling and application of quick tests

Guidelines for the management

of HIV and other STIs

Country

Recommendations

CDC, 2016

HEALTH, 2015

WHO, 2015

NACP, 2013

CENSIDA, 2006

CDC, 2016

NICE, 2016

HEALTH, 2015

MSSSI, 2014

NACP, 2013

HAS, 2009

BHIVA, 2008

HAS, 2008

CENSIDA, 2006

NICE, 2017

CDC, 2016

NICE, 2016

WHO, 2016

HEALTH, 2015

MSSSI, 2014

CENSIDA, 2006

NICE, 2017

CDC, 2016

NICE, 2016

HEALTH, 2015

MSSSI, 2014

NACP, 2013

HAS, 2009

CENSIDA, 2006

NICE, 2016

HEALTH, 2015

NACP, 2013

HAS, 2009

HAS, 2008

NICE, 2016

CDC, 2016

HEALTH, 2015

WHO, 2015

MSSSI, 2014

NACP, 2013

CENSIDA, 2006

HEALTH, 2015

NACP, 2013
United States

South Africa

International

Tanzania

Mexico

United States

England

South Africa

Spain

Tanzania

France

British

France

Mexico

England

United States

England

International

South Africa

Spain

Mexico

England

United States

England

South Africa

Spain

Tanzania

France

Mexico

England

South Africa

Tanzania

France

France

England

United States

South Africa

International

Spain

Tanzania

Mexico

South Africa Tanzania
Both psychological counseling and rapid testing should be carried out with professional and ethical responsibility, based on human rights and developed in a supportive environment. Accordingly, every person must be treated with dignity and equality, not discriminated against and receive fair work practices.

Ensure and underline the fact that all information concerning the user is strictly confidential (health status, results, treatment, risk practices).

The user's consent can be verbal, except in the case of research, children, or people with cognitive impairment, in which case it will have to be written.

Psychological counseling and rapid testing are voluntary processes, the user has the right to request information and ask questions at any time. They also have the right to withdraw their consent at any time during the process without their decision having an impact on access to health services and they must be provided with sufficient information and referrals to other health services which they can seek at a later date.

In order for the user to decide whether or not to give their consent, they must be given clear, concise information, about the forms of infection, transmission, timely diagnosis, treatment, as well as the benefits, implications and procedures for psychological counseling and rapid testing.

Psychological counseling and rapid testing services should include sufficient, accurate user-centered information that addresses their needs and risks.

Psychological counseling and rapid testing services must be regulated by standardized operating procedures to ensure the quality and reliability of the process to provide correct results to users, meaning that they must be monitored and evaluated. 
Table 1 (Continued)

\begin{tabular}{|c|c|c|}
\hline About the counselors & Country & \\
\hline CDC, 2016 & United States & \multirow{6}{*}{$\begin{array}{l}\text { A counselor can be anyone who has been trained to provide orientation services and apply } \\
\text { rapid testing. }\end{array}$} \\
\hline NICE, 2016 & England & \\
\hline WHO, 2015 & International & \\
\hline HEALTH, 2015 & South Africa & \\
\hline NACP, 2013 & Tanzania & \\
\hline HAS, 2009 & France & \\
\hline CDC, 2016 & United States & \multirow{5}{*}{$\begin{array}{l}\text { Counselors should have supervision and training, at least once a year, to perform proce } \\
\text { dures safely and effectively. }\end{array}$} \\
\hline NICE, 2016 & England & \\
\hline HEALTH, 2015 & South Africa & \\
\hline WHO, 2015 & International & \\
\hline NACP, 2013 & Tanzania & \\
\hline CDC, 2016 & United States & \multirow{5}{*}{$\begin{array}{l}\text { Simple, clear language that is understandable and appropriate for the user should be } \\
\text { used. A friendly, respectful, sensitive and discreet approach should be adopted. }\end{array}$} \\
\hline HEALTH, 2015 & South Africa & \\
\hline MSSSI, 2014 & Spain & \\
\hline NACP, 2013 & Tanzania & \\
\hline CENSIDA, 2006 & Mexico & \\
\hline
\end{tabular}

Notes: CDC: Centers for Disease Control; HEALTH: the National Department of Health Republic of South Africa; WHO: World Health Organization; NACP: National AIDS Control Program; CENSIDA: National Center for the Prevention and Control of HIV and AIDS; NICE: National Institute of Clinical and Healthcare Excellence; MSSSI: Ministry of Health, Social Services and Equality; HAS: Haute Autorité de Santé; BHIVA: British HIV Association, British Association of Sexual Health and HIV, British Infection Society; PEP: Post-exposure prophylaxis; PrEP: Pre-exposure Prophylaxis.

of HIV and other STIs, and c) the exploration of risky behaviors (sexual practices and injected drug use), which will be described later.

\section{Section 2: Feasibility Study}

\section{Cognitive laboratories}

In order to systematically capture the procedures of the $O P B-A P R$ model, a standardized manual/guide was developed, which underwent a cognitive laboratory process to ensure that the theoretical content, support materials and graphic resources were cognitively ergonomic (clear, understandable and intuitive), for the health professionals who would be trained in the model.

Each cognitive laboratory was made up of at least ten people, including health professionals (doctors, nurses and psychologists). The cognitive laboratories were carried out in three stages: content presentation, information gathering and consensus groups. In the first stage, each participant read the information corresponding to the components of the model, with the aim of identifying words, ideas or fragments that were difficult to understand. In the second stage, participants received semi-structured questionnaires (which included open-ended and multiple-choice questions) to express their comments, which included recommendations to improve the understanding of the fragments identified.

In the third stage, a member of the collaborative work team presented the problematic words, ideas or fragments, as well as the recommendations made. Subsequently, a discussion between the participants was coordinated with the aim of agreeing on the recommendations that would be used to increase understanding of the documents presented. Lastly, the collaborative work team incorporated the suggested modifications for each component, which resulted in the final design of the $O P B-A P R$ model manual/guide.

\section{Field team formation and training}

Three field teams were formed, each comprising six non-specialized health professionals (psychologists, nurses and general practitioners), with the aim of conducting feasibility tests on the $O P B-A P R$ model.

Likewise, specific training was developed for the field teams in order for their members to develop the skills (knowledge, attitudes and skills) required for the implementation of the procedures and components of the $O P B-A P R$ model.

The training lasted 42 hours, divided into seven six-hour sessions. The first session consisted of the presentation of basic aspects of HIV and other STIs, as well as their relationship with SUDs. The second session focused on the basic characteristics of psychological counseling. The third session addressed the exploration of risky sexual behaviors in people who use alcohol and other substances of abuse. The fourth session dealt with the brief, specific psychological counseling for the application of rapid HIV, HBV, HCV and syphilis tests. Sessions five and six focused on the management and application of rapid testing. Session seven provided a detailed explanation of the study and model procedures and implemented skills development strategies such as modeling and role play. At the end of the training, participants' understanding of $O P B-A P R$ model procedures was tested. 
Table 2

Considerations for the process of counseling and application of quick tests

Guidelines for the management

of HIV and other STIs

Country

Recommendations

CDC, 2016

HAS, 2008

CDC, 2016

HEALTH, 2015

CDC, 2016

HEALTH, 2015

BHIVA, 2008

CDC, 2016

HEALTH, 2015

NOM-045

NOM-087

CDC, 2016

HEALTH, 2015

NACP, 2013

NACP, 2013

CDC, 2016

NACP, 2013

HEALTH, 2015

HEALTH, 2015

NACP, 2013

NOM-087
United States

France

United States

South Africa

United States

South Africa

British

United States

South Africa

Mexico

Mexico

United States

South Africa

Tanzania

Tanzania

United States

Tanzania

South Africa

South Africa

Tanzania

Mexico
Rapid testing can be applied in various non-clinical settings, since they do not require specialized equipment or invasive sample collection, and they can be applied and the results given back the same day.

The application manuals, material and brochures used must be available and accessible to the counselor.

Services must be offered in a private space that guarantees confidentiality, has adequate infrastructure (clean conditions, good lighting and temperature) and is comfortable for the user.

Counselors must carry use universal safety procedures for fluid handling such as:

Washing hands before and after handling blood. If soap and water are unavailable, hand sanitizer gel must be used.

Wearing latex gloves and putting on a new pair for each user.

Not eating, drinking or handling contact lenses in the test area.

Disinfecting the work surface with chlorine.

If the counselor has direct contact with the user's blood, they must report it to their supervisor and seek medical assistance.

The manufacturing instructions contained in the packages of each test must be followed.

Counselors must use the specific diluting liquid for each test, making sure it has not passed its expiry date. If they have expired, they should not be used.

Quick tests can be performed in the same place where the counseling is provided. In this case, the tests must be covered or put in an area not visible to the user while waiting to see the result.

Test results must be read within the period of time specified in the manufacturers' instructions.

Ensure that the red test control line appears. If it does not appear, this indicates that the test has failed to meet the quality criteria.

Used materials, lancets, gauze, cotton or any material that may contain blood must be disposed of in specific containers.

Notes: CDC: Centers for Disease Control; HEALTH: the National Department of Health Republic of South Africa; WHO: World Health Organization; NACP: National AIDS Control Program; CENSIDA: National Center for the Prevention and Control of HIV and AIDS; NICE: National Institute of Clinical and Healthcare Excellence; MSSSI: Ministry of Health, Social Services and Equality; HAS: Haute Autorité de Santé; BHIVA: British HIV Association, British Association of Sexual Health and HIV, British Infection Society; NOM: Official Mexican Standard.

\section{Field tests}

For the field tests, the collaborative work teams of UEC-INPRFM and CENSIDA formed three field work teams, each consisting of five psychologists and a supervisor (a doctor or a psychologist). All members of the field work team were certified in the $O P B-A P R$ model procedures. Field tests were carried out in residential $(n=31)$ and outpatient $(n=10)$ treatment centers in four states in Mexico (Mexico City, Puebla, Mexico State, and Hidalgo), achieving a total of 600 applications of $O P B-A P R$ model procedures. For more information on the research protocol and results, see the associated articles (Sánchez-Domínguez,
Villalobos-Gallegos, Félix-Romero, Morales-Chainé, \& Marín-Navarrete, 2017; Villalobos-Gallegos et al, 2019; Marín-Navarrete, Magis-Rodríguez, Medina-Mora, \& Uribe-Zúñiga, 2019; Marín-Navarrete, Villalobos-Gallegos, Medina-Mora, \& Magis-Rodríguez, 2019).

\section{Section 3: Integration of the final version of the OPB-APR model}

Throughout the process, meetings were periodically held between the collaborative work and field teams to identify procedures that might experience complications when implemented in real treatment scenarios for SUDs. During the meetings, the procedures were evaluated and field staff 
Table 3

Considerations regarding of substance users

Guidelines for the management

of HIV, HCV and other STIS

Country

Recommendations

WHO, 2016

NICE, 2016

HEALTH, 2015

WHO, 2014

MSSSI, 2014

NACP, 2013

HAS, 2009

NICE, 2016

WHO, 2016

NICE, 2016
International

International

England

South Africa

International

Spain

Tanzania

France

England

is recommended to offer and recommend the tests to people with a high risk of contracting or transmitting a STI in the event that no screening tests have been performed in the past year.

It is not recommended to apply rapid testing to users who are already under antiretroviral treatment, have taken the PEP or PrEP, as there is a potential risk of an incorrect diagnosis.

England

Psychological counseling and application of rapid testing should be offered and recommended for anyone as part of routine general health care or for those taking part in a substance management program, as an effective, efficient way to identify STIs (such as HIV, hepatitis B, hepatitis C, syphilis, lymphoma and tuberculosis).

People who are under the influence of drugs, alcohol or other mental disorders should not be evaluated, since they are not in a position to give their consent.

Notes: CDC: Centers for Disease Control; HEALTH: the National Department of Health Republic of South Africa; WHO: World Health Organization; NACP: National AIDS Control Program; CENSIDA: National Center for the Prevention and Control of HIV and AIDS; NICE: National Institute of Clinical and Healthcare Excellence; MSSSI: Ministry of Health, Social Services and Equality; HAS: Haute Autorité de Santé; BHIVA: British HIV Association, British Association of Sexual Health and HIV, British Infection Society; PEP: Post-exposure prophylaxis; PrEP: Pre-exposure Prophylaxis.

were given feedback to increase adherence to the $O P B-A P R$ model components. Lastly, comments and recommendations that had arisen during the meetings were used to draft the final version of the $O P B-A P R$ model manual/guide.

\section{Ethical considerations}

This study was implemented with the approval of the INPRFM Research Ethics Committee (CEI/C071/2016). Likewise, all procedures were performed in accordance with good research practices in human subjects, and both participating patients and health professionals gave their written consent for inclusion in the study (Marín-Navarrete, Villalobos-Gallegos et al., 2019).

\section{RESULTS}

After the multi-stage process, the final version of the $O P B$ $A P R$ model was obtained, whose main objective is the detection of new cases of HIV infection and other STIs to refer them to antiretroviral treatment. It also seeks to increase the perception of risk of situations and behaviors associated with contracting or transmitting a STI or BBV, in addition to promoting the development of personalized strategies to prevent and reduce the risk of infection.

The $O P B-A P R$ model consists of two parts: the first part explores and provides feedback on risk behaviors and situations (risky sexual behavior and substance use) for contracting STIs or BBVs. The second part focuses on providing feedback on the rapid testing results, as well as offering specific recommendations for risk prevention and reduction. The whole procedure lasts approximately 30 minutes.

Specifically, the $O P B-A P R$ model consists of five focused steps (Figure 1):

- Step 1. Presentation and description of the procedure: In this step, the counselor provides general information on the procedure, requests written informed consent and provides answers on the information provided.

- Step 2. Application of rapid tests: This involves aseptic procedures, blood sampling through finger pricks, using a reagent kit and disposing of materials.

- Step 3. Exploration of and feedback on risk behaviors: This consists of applying the questionnaire on risky sexual behaviors and the use of alcohol and other substances of abuse.

- Step 4. Reporting results: This step involves reviewing and analyzing the results of the rapid testing, considering the information obtained in the forms. In addition, feedback is provided on the results and a risk reduction plan is drawn up.

- Step 5. Reference to services and delivery of information brochures: This final step is designed to provide patients with brochures with general 
Table 4

Considerations for giving back results and referral to health services

Guidelines for the management

of HIV and other STIs

Country

Recommendations

$\begin{array}{lll}\text { NICE, } 2016 & \text { England } & \text { Results must always be given back as part of counseling, clearly, directly and without } \\ \text { MSSSI, } 2014 & \text { Spain } & \text { redundancy, regardless of the test result. Behavior focusing on the user's health should be } \\ \text { NOM-010 } & \text { Mexico } & \text { promoted, and referrals made to health services considered necessary. }\end{array}$

HAS, 2008 France

NICE, $2016 \quad$ England Counselors should be aware of and have information on the health centers and places HEALTH, 2015 South Africa where they can refer users to obtain information on STIs, sexual health, conducting conNACP, 2013 Tanzania firmatory tests, interventions for behavioral change, reviewing health status, psychosocial

NON-reactive result $\quad$ Country support and/or rehabilitation for substance use, among other aspects.

NICE, $2016 \quad$ England Users who obtain non-reactive results in their tests should be provided with information

HEALTH, 2015

MSSSI, 2014

South Africa on prevention, risk reduction and referral to health services in order to be able to access

CDC, 2016

Spain

NICE, 2016

United States various care and prevention options.

WHO, 2016

England

If the user obtains non-reactive results in their rapid testing, but has recently engaged in

HEALTH, 2015

International

risky behaviors or been exposed to risk, repeating the tests once the window period has

NACP, 2013

South Africa passed, and providing information on care and prevention is recommended.

HAS, 2009

Tanzania

France

HAS, 2008

CENSIDA, 2006

France

Mexico

WHO, 2016

International

If the user obtains a non-reactive result, and does not report risk behaviors, it is not nec-

HEALTH, 2015

South Africa essary to repeat the test. They should be provided with information on health services in

NACP, 2013

Tanzania case they wish to repeat them at a later date.

\begin{tabular}{|c|c|c|}
\hline Invalid result & Country & \\
\hline $\begin{array}{l}\text { CDC, } 2016 \\
\text { WHO, } 2016 \\
\text { HEALTH, } 2015 \\
\text { NACP, } 2013 \\
\text { CENSIDA, } 2006\end{array}$ & $\begin{array}{l}\text { United States } \\
\text { International } \\
\text { South Africa } \\
\text { Tanzania } \\
\text { Mexico }\end{array}$ & $\begin{array}{l}\text { If the user obtains an invalid result in any of their tests, which means that a human error } \\
\text { or a mistake involving the test properties has occurred, the test must immediately be re- } \\
\text { peated using a new kit. } \\
\text { If an invalid result is obtained for the second time, information must be provided to the user } \\
\text { so that they can have a confirmatory test. }\end{array}$ \\
\hline Reactive result & Country & \\
\hline $\begin{array}{l}\text { CDC, } 2016 \\
\text { WHO, } 2016 \\
\text { NICE, } 2016 \\
\text { HEALTH, } 2015 \\
\text { MSSSI, } 2014 \\
\text { HAS, } 2008 \\
\text { CENSIDA, } 2006\end{array}$ & $\begin{array}{l}\text { United States } \\
\text { International } \\
\text { England } \\
\text { South Africa } \\
\text { Spain } \\
\text { France } \\
\text { Mexico }\end{array}$ & $\begin{array}{l}\text { Rapid tests do not provide a definitive diagnosis. Users who obtain reactive results should } \\
\text { be referred to health services that provide confirmatory tests. They should be given infor- } \\
\text { mation on safe sex practices and risk behaviors. }\end{array}$ \\
\hline Re-testing & Country & \\
\hline $\begin{array}{l}\text { WHO, } 2016 \\
\text { HEALTH, } 2015 \\
\text { MSSSI, } 2014 \\
\text { HAS, } 2009 \\
\text { BHIVA, } 2008\end{array}$ & $\begin{array}{l}\text { International } \\
\text { South Africa } \\
\text { Spain } \\
\text { France } \\
\text { British }\end{array}$ & $\begin{array}{l}\text { Recommend people who are at risk of contracting or transmitting an STI or who are at risk } \\
\text { of exposure to take the tests annually. }\end{array}$ \\
\hline $\begin{array}{l}\text { WHO, } 2016 \\
\text { NICE, } 2016 \\
\text { BHIVA, } 2008\end{array}$ & $\begin{array}{l}\text { International } \\
\text { England } \\
\text { British }\end{array}$ & $\begin{array}{l}\text { MSM are recommended to have tests done annually. In the event that they have unpro- } \\
\text { tected sex or casual sexual partners, they are recommended to have tests every three } \\
\text { months }\end{array}$ \\
\hline
\end{tabular}

Notes: CDC: Centers for Disease Control; HEALTH: the National Department of Health Republic of South Africa; WHO: World Health Organization; NACP: National AIDS Control Program; CENSIDA: National Center for the Prevention and Control of HIV and AIDS; NICE: National Institute of Clinical and Healthcare Excellence; MSSSI: Ministry of Health, Social Services and Equality; HAS: Haute Autorité de Santé; BHIVA: British HIV Association, British Association of Sexual Health and HIV, British Infection Society; NOM: Official Mexican Standard. 


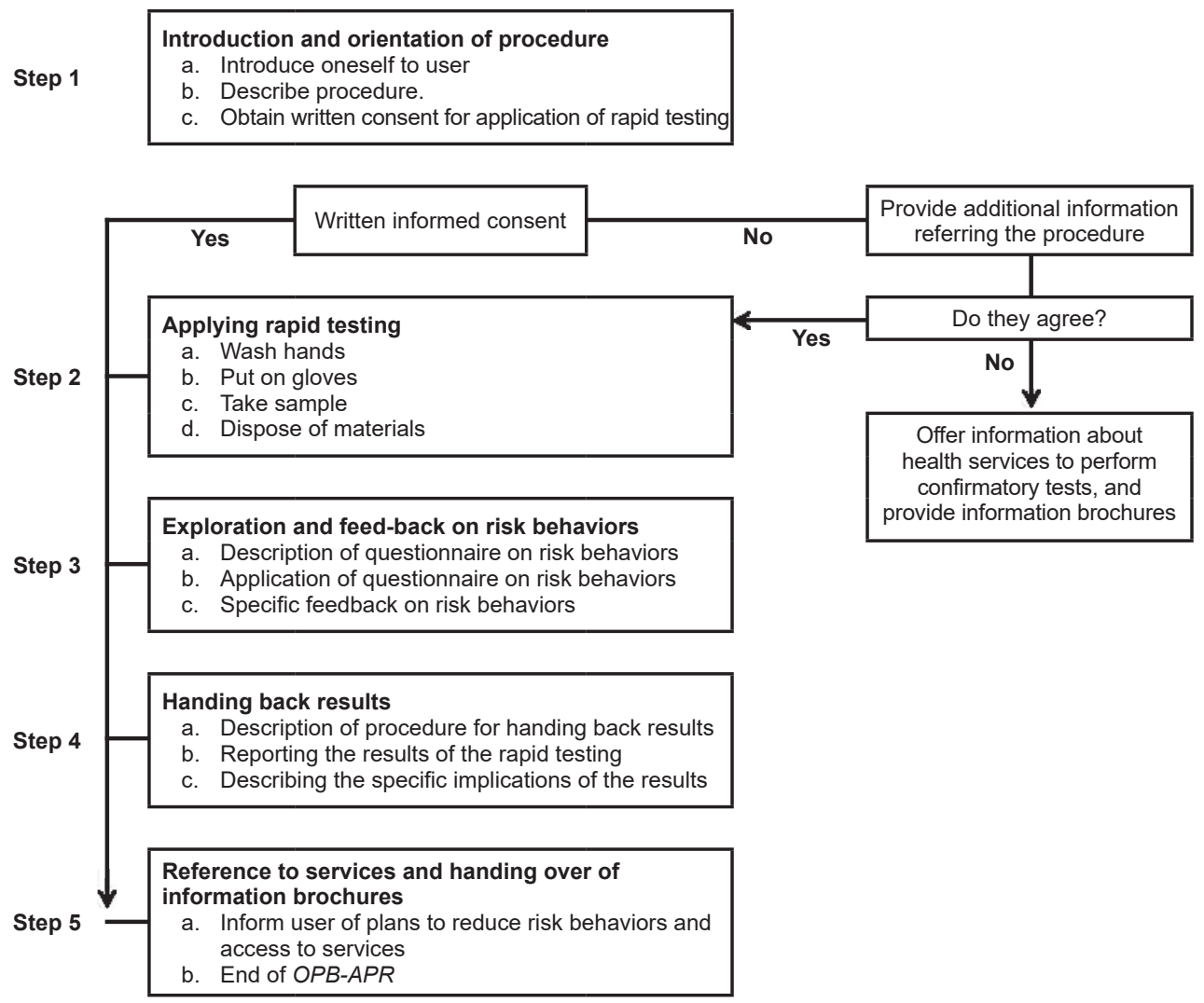

Figure 1. $O P B-A P R$ model diagram.

information on STIs and safe sex practices. Cases with reactive results are informed about public care services where they can have confirmatory tests and receive comprehensive treatment that includes ART.

\section{DISCUSSION AND CONCLUSIONS}

Using substances by any route of administration increases the risk of contracting a STI, co-infections, medical complications, poor adherence to antiretroviral treatments and therefore increases morbidity and mortality rates. In this respect, SUDs form a transverse axis that significantly impacts vulnerable groups and key populations (Marín-Navarrete, et al., 2017; Marín-Navarrete, Magis-Rodríguez, et al., 2019).

The purpose of this article was to present the narrative of the process for the development of a standardized model based on scientific evidence for the detection, orientation and referral of people with HIV, HBV, HCV and syphilis at addiction treatment centers in the Mexican public health system. This aim is based on the theoretical assumption that the detection of probable cases increases access to antiretroviral therapy (ART), which is associated with a reduction in the transmission, progression and death of people due to advanced immunological disease. It also seeks to adhere to the recommendations of the US Preventive Services Task Force on the application of rapid testing to all those at increased risk of contracting HIV, HCV and other STIs (Moyer, 2013), and of WHO for the implementation of harm reduction strategies (The Joint United Nations Program on HIV/AIDS [UNAIDS], 2016).

As a result of the process, the $O P B-A P R$ model was obtained, which was developed with the goal of constructing a standardized model based on scientific evidence that will contribute to strengthening the public health system in Mexico as a fundamental element in achieving the goal established by UNAIDS known as 90-90-90, which sets three specific goals in the HIV/AIDS care cascade for 2020: (1) $90 \%$ of all PLHIV will know their serological status; (2) $90 \%$ of all people diagnosed with HIV will receive sustained ART; and $90 \%$ of all people receiving ART will achieve viral suppression (The Joint United Nations Program on HIV/AIDS [UNAIDS], 2014), and HIV will have been eradicated worldwide by 2030 (UNAIDS, 2014).

Likewise, having a detection, orientation and referral model, based on scientific evidence, contributes to the reduction of barriers that exist in health services (Schneider et al., 2006; Rawat, Uebel, Moore, Cingl, \& Yassi 2018), 
and the personal barriers that influence the initiation of ART (Posse, Meheus, Van Asten, H., Van Der Ven, \& Baltussen, 2008; Johnson et al., 2015). Barriers reported by various studies include lack of training in the application of rapid tests. This can be offset by basic training to offer psychological guidance, provide feedback on safe sexual behaviors to reduce the likelihood of transmission of HIV and other STIs, and liaise with health services for the application of supplementary (confirmatory) tests and/or initiating ART (Posse et al., 2008; Rawat et al., 2018; Johnson et al., 2015) to prevent late diagnoses and ensure that PLHIV improve their quality of life through early detection (Magis-Rodríguez, Villafuerte-García, Cruz-Flores, \& Uribe-Zuniga, 2015).

In Mexico, implementing a permanent program for monitoring risk behaviors and detecting HIV, HCV and other STIs in the population of people receiving treatment for SUDs can be a major task for a single system (CAPASIT and SAIH), since the universe of people with SUDs is larger than that of people with HIV, HCV and other STIs. Thus, incorporating professionals from addiction treatment centers in the public system into a permanent program for detection, orientation and referral could significantly strengthen the actions for achieving the eradication of HIV by 2030, in addition to significantly impacting the detection and care of $\mathrm{HCV}$ and other STIs.

In this respect, the $O P B-A P R$ model can serve as a key element in the implementation of risk and harm reduction strategies in people who use substances of abuse by any route of administration.

Another advantage of this proposal is that the $O P B$ $A P R$ model would enable the homologation of procedures between health professionals who are specialized in HIV and other STIs and those who are not (general practitioners, nurses, psychologists, etc.) for their performance in clinical and community settings. Since it is a standardized procedure, it would be feasible to transfer the implementation of the model to community agents who have direct contact with members of key populations, including PWIDs and thus strategically contribute to the country's efforts to prevent HIV and other STIs.

\section{Funding}

This study was funded by the National Council of Science and Technology (CONACYT) grant number 262500 awarded to RMN. During the development of the manuscript, LVG received funding from the National Council of Science and Technology (CONACYT) through doctoral award no. 383294.

\section{Conflict of interest}

The authors declare they have no conflict of interest. Neither INPRFM nor CENSIDA took part in the analysis of the information, preparation of the manuscript or the decision to publish. This paper reflects the opinions of the authors alone.

\section{Acknowledgements}

The authors express their gratitude to Centros de Integración Juvenil A.C., the Instituto Mexiquense Contra las Adicciones, the Instituto para la Atención y Prevención de las Adicciones de la CDMX and the Consejo Estatal Contra las Adicciones de Puebla, for their institutional support in implementing this study.

\section{REFERENCES}

Altice, F. L., Kamarulzaman, A., Soriano, V. V., Schechter, M., \& Friedland, G. H. (2010). Treatment of medical, psychiatric, and substance-use comorbidities in people infected with HIV who use drugs. The Lancet, 376(9738), 367-387. doi: 10.1016/S0140-6736(10)60829-X

Benhamou, Y., Bochet, M., Di Martino, V., Charlotte, F., Azria, F., Coutellier, A., ... Poynard, T. (1999). Liver fibrosis progression in human immunodeficiency virus and hepatitis C virus coinfected patients. Hepatology, 30(4), 1054-1058. doi: 10.1002/hep.510300409

Centers for Disease Control and Prevention. (2019). Syphilis Surveillance Supplement 2013-2017. Atlanta, Georgia: U.S. Department of Health and Human Services. Retrieved from: https://www.cdc.gov/std/stats17/syphilis2017/SyphilisSurveillance-Supplement-2013-2017.pdf

Centro de Investigación en Enfermedades Infecciosas [CIENI]. (2011). 30 años del VIH-SIDA: Perspectivas desde México. Mexico: CIENI. Retrieved from: http://www.censida.salud.gob.mx/descargas/biblioteca/ documentos/30aniosdelvihsida.pdf

Centro Nacional para la Prevención y Control del VIH y el sida [CENSIDA]. (2019). Guías y Manuales. Mexico. Retrieved from: https://www.gob.mx/censida/ articulos/guias-y-manuales-censida?idiom=es

Chander, G., Himelhoch, S., \& Moore, R. D. (2006). Substance abuse and psychiatric disorders in HIV-positive patients. Drugs, 66(6), 769-789. doi: 10.2165/00003495-200666060-00004

Fundación Mexicana para la Salud Hepática. (2011). La hepatitis C como un problema de salud pública en México. Salud Pública de México, 53(Supl 1), S61-S67. ISSN: 0036-3634

Grebely, J., \& Tyndall, M. W. (2011). Management of HCV and HIV infections among people who inject drugs. Current Opinion in HIV and AIDS, 6(6), 501507. doi: 10.1097/COH.0b013e32834bcb36

Johnson, M., Samarina, A., Xi, H., Valdez Ramalho Madruga, J., Hocqueloux, L., Loutfy, M., ... Martinez, M. (2015). Barriers to access to care reported by women living with HIV across 27 countries. AIDS Care, 27(10), 1220-1230. doi: 10.1080/09540121.2015.1046416

Klinkenberg, W. D., Sacks, S., \& HIV/AIDS Treatment Adherence, Health Outcomes and Cost Study Group. (2004). Mental disorders and drug abuse in persons living with HIV/AIDS. AIDS Care, 16(Supp1), S22-S42. doi: 10.1080/09540120412331315303

Magis-Rodríguez, C. L., Villafuerte-García, A., Cruz-Flores, R. A., \& Uribe-Zuniga, P. (2015). Delayed initiation of antiretroviral therapy in Mexico. Salud Publica de Mexico, 57(Suppl 2), s127-s134. PMID:26545128

Marcus, U., Bremer, V., Hamouda, O., Kramer, M. H., Freiwald, M., Jessen, H., ... Zimmer, Y. (2006). Understanding recent increases in the incidence of sexually transmitted infections in men having sex with men: Changes in risk behavior from risk avoidance to risk reduction. Sexually Transmitted Diseases, 33(1), 11-17. doi: 10.1097/01.olq.0000187224.10428.31

Marín-Navarrete, R., Medina-Mora, M. E., \& Tena-Suck, A. (2014). Breve panorama del tratamiento de las adicciones en México. A. Tena-Suck y R. Marín N. (Eds.). Temas Selectos en Orientación Psicológica VIII: Orientación Psicológica y Adicciones, (1-7).

Marín-Navarrete, R., Magis-Rodríguez, C., \& Strathdee, S. A. (2017). Sexually transmitted infections and substance use disorders: evidence and challenges in Mexico. Salud Mental, 40(1), 1-4. doi: 10.17711/SM.0185-3325.2017.001

Marín-Navarrete, R., Medina-Mora, M. E., Pérez-López, A., \& Horigian, V. E. (2018). Development and evaluation of addiction treatment programs in Latin America. Current Opinion in Psychiatry, 31(4), 306-314. doi: 10.1097/ 
YCO.0000000000000434

Marín-Navarrete, R., Magis-Rodríguez, C., Medina-Mora, M. E., \& Uribe-Zuñiga, P. E. (2019). Guía para la detección, orientación y referencia del VIH y otras ITS en centros para la atención de adicciones. Mexico: INPRFM, CENSIDA.

Marín-Navarrete, R., Villalobos-Gallegos, L., Medina-Mora, M. E., \& MagisRodríguez, C. (2019). Rapid testing and counseling for HIV/STIs in Mexican community-based residential care facilities for substance use disorders: A prospective study protocol. Journal of Substance Use, 24(3), 329-335. doi: $10.1080 / 14659891.2019 .1572801$

Moyer, V. A. (2013). Screening for hepatitis C virus infection in adults: US Preventive Services Task Force recommendation statement. Annals of Internal Medicine, 159(5), 349-357. doi: 10.7326/0003-4819-159-5-201309030-00672

Posse, M., Meheus, F., Van Asten, H., Van Der Ven, A., \& Baltussen, R. (2008). Barriers to access to antiretroviral treatment in developing countries: a review. Tropical Medicine \& International Health, 13(7), 904-913. doi: 10.1111/j.13653156.2008.02091.x

Quinn, T. C., Wawer, M. J., Sewankambo, N., Serwadda, D., Li, C., WabwireMangen, F., ... Gray, R. H. (2000). Viral load and heterosexual transmission of human immunodeficiency virus type 1. New England Journal of Medicine, 342(13), 921-929. doi: 10.1056/NEJM200003303421303

Rabkin, J. G., McElhiney, M. C., \& Ferrando, S. J. (2004). Mood and substance use disorders in older adults with HIV/AIDS: methodological issues and preliminary evidence. AIDS, 18(Suppl 1), S43-S48. PMID: 15075497

Rawat, A., Uebel, K., Moore, D., Cingl, L., \& Yassi, A. (2018). Patient responses on quality of care and satisfaction with staff after integrated HIV care in South African Primary Health Care Clinics. Journal of the Association of Nurses in AIDS Care, 29(5), 698-711. doi: 10.1016/j.jana.2018.04.014

Rhodes, T., Platt, L., Maximova, S., Koshkina, E., Latishevskaya, N., Hickman, M. ... Parry, J. V. (2006). Prevalence of HIV, hepatitis C and syphilis among injecting drug users in Russia: a multi-city study. Addiction, 101(2), 252-266. doi: 10.1111/j.1360-0443.2006.01317.x

Sánchez-Domínguez, R., Villalobos-Gallegos, L., Félix-Romero, V., MoralesChainé, S., \& Marín-Navarrete, R. (2017). Effect of substance use on condom use in the Theory of Planned Behavior: Analysis of differential item functioning. Salud Mental, 40(1), 5-14. doi: 10.17711/SM.0185-3325.2017.002

Scheinmann, R., Hagan, H., Lelutiu-Weinberger, C., Stern, R., Des Jarlais, D. C., Flom, P. L., \& Strauss, S. (2007). Non-injection drug use and hepatitis C virus: A systematic review. Drug and Alcohol Dependence, 89(1), 1-12. doi: 10.1016/j.drugalcdep.2006.11.014

Schneider, H., Blaauw, D., Gilson, L., Chabikuli, N., \& Goudge, J. (2006). Health systems and access to antiretroviral drugs for HIV in Southern Africa: service delivery and human resources challenges. Reproductive Health Matters, 14(27), 12-23. doi: 10.1016/S0968-8080(06)27232-X

Singh, K. P., Crane, M., Audsley, J., Avihingsanon, A., Sasadeusz, J., \& Lewin, S. R. (2017). HIV-hepatitis B virus coinfection: epidemiology, pathogenesis, and treatment. AIDS, 31(15), 2035-2052. doi: 10.1097/QAD.0000000000001574

Strathdee, S. A., Philbin, M. M., Semple, S. J., Pu. M., Orozovich, P., Martinez, G. ... Patterson, T. L. (2008). Correlates of injection drug use among female sex workers in two Mexico-U.S. border cities. Drug and Alcohol Dependence, 92(13), 132-140. doi: 10.1016/j.drugalcdep.2007.07.001

Sulkowski, M. S., Thomas, D. L., Chaisson, R. E., \& Moore, R. D. (2000). Hepatotoxicity associated with antiretroviral therapy in adults infected with human immunodeficiency virus and the role of hepatitis C or B virus infection. JAMA, 283(1), 74-80. doi: 10.1001/jama.283.1.74

Szerman, N., Martínez-Raga, J., Baler, R., Roncero, C., Vega, P., Basurte, I., ... Spinnato, G. (2017). Joint statement on dual disorders: Addiction and other mental disorders. Salud mental, 40(6), 245-247. doi: 10.17711/SM.01853325.2017.031

The Joint United Nations Programme on HIV/AIDS [UNAIDS]. (2014). 90-90-90: A transformative agenda to leave no one behind. In: Launch of Vietnam's 9090-90 initiative (pp. 2-8).

The Joint United Nations Programme on HIV/AIDS [UNAIDS]. (2016). Do no harm: Health, human rights and people who use drugs. Geneva, Switzerland: Joint United Nations Programme on HIV/AIDS.

Thio, C. L., Seaberg, E. C., Skolasky, R. Jr., Phair, J., Visscher, B., Muñoz, A., \& Thomas, D. L. (2002). HIV-1, hepatitis B virus, and risk of liver-related mortality in the Multicenter Cohort Study (MACS). The Lancet, 360(9349), 1921-1926. doi: 10.1016/s0140-6736(02)11913-1

Treloar, C., Newland, J., Rance, J., \& Hopwood, M. (2010). Uptake and delivery of hepatitis $\mathrm{C}$ treatment in opiate substitution treatment: perceptions of clients and health professionals. Journal of Viral Hepatitis, 17(12), 839-844. doi: 10.1111/j.1365-2893.2009.01250.x

Villalobos-Gallegos, L., Medina-Mora, M. E., Benjet, C., Ruiz-Velasco, S., MagisRodriguez, C., \& Marín-Navarrete, R. (2019). Multidimensional patterns of sexual risk behavior and psychiatric disorders in men with substance use disorders. Archives of Sexual Behavior, 48(2), 599-607. doi: 10.1007/s10508-018-1227-2

Wong, W., Chaw, J. K., Kent, C. K., \& Klausner, J. D. (2005). Risk factors for early syphilis among gay and bisexual men seen in an STD clinic: San Francisco, 2002-2003. Sexually Transmitted Diseases, 32(7), 458-463. doi: 10.1097/01. olq. 0000168280.34424 .58 